\title{
Formation and emission of hydrogen chloride in indoor air
}

\author{
Kathryn E. R. Dawe ${ }^{a}$, Teles C. Furlani ${ }^{a, b}$, Shawn F. Kowal ${ }^{c}$, Tara F. Kahan ${ }^{\text {, }}$ Trevor C. \\ VandenBoer $^{\mathrm{b}, \mathrm{d}}$, and Cora J. Young ${ }^{\mathrm{a}, \mathrm{b}}$
}

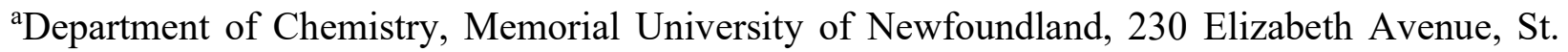
John's, NL A1B 3X7 Canada

${ }^{b}$ Department of Chemistry, York University, 4700 Keele Street, Toronto, ON M3J 1P3 Canada

${ }^{\mathrm{c} D e p a r t m e n t}$ of Chemistry, Syracuse University, 111 College Place Syracuse, New York 13244 United States

${ }^{\mathrm{d} D e p a r t m e n t}$ of Earth Sciences, Memorial University of Newfoundland, 9 Arctic Avenue, St. John's, NL A1B 3X5 Canada

Correspondence to: youngcj@yorku.ca

\section{This is the peer reviewed version of the following article:}

Dawe, K.E.R., Furlani, T.C., Kowal, S.F., Kahan, T.F., VandenBoer, T.C., Young, C.J. 2019

Formation and emission of hydrogen chloride in indoor air. Indoor Air 29:70-78, doi:10.1111/ina.12509,

which has been published in final form at https://onlinelibrary.wiley.com/doi/10.1111/ina.12509.

This article may be used for non-commercial purposes in accordance with Wiley Terms and Conditions for Use of Self-Archived Versions. This article may not be enhanced, enriched or otherwise transformed into a derivative work, without express permission from Wiley or by statutory rights under applicable legislation. Copyright notices must not be removed, obscured or modified. The article must be linked to Wiley's version of record on Wiley Online Library and any embedding, framing or otherwise making available the article or pages thereof by third parties from platforms, services and websites other than Wiley Online Library must be prohibited. 


\section{Abstract}

To improve our understanding of chlorine chemistry indoors, reactive chlorine species such as hydrogen chloride $(\mathrm{HCl})$ must be analyzed using fast time-response measurement techniques. Although well studied outdoors, sources of $\mathrm{HCl}$ indoors are unknown. In this study, mixing ratios of gaseous $\mathrm{HCl}$ were measured at $0.5 \mathrm{~Hz}$ in the indoor environment using a cavity ringdown spectroscopy (CRDS) instrument. The CRDS measurement rate provides a major advance in observational capability compared to other established techniques. Measurements of $\mathrm{HCl}$ were performed during three types of household activities: (1) floor exposure to bleach, (2) chlorinated and non-chlorinated detergent use in household dishwashers, and (3) cooking events. Surface application of bleach resulted in a reproducible increase of $0.1 \mathrm{ppbv}$ in the affected room. Emissions of $\mathrm{HCl}$ from automated dishwashers were observed only when chlorinated detergents were used, with additional $\mathrm{HCl}$ emitted during the drying cycle. Increased mixing ratios of $\mathrm{HCl}$ were also observed during meal preparation on an electric element stovetop. These observations of $\mathrm{HCl}$ derived from household activities indicate either direct emission or secondary production of $\mathrm{HCl}$ via chlorine atoms is possible. Calculations of photolysis rate constants of chlorine atom precursors provide evidence that photolysis may contribute to indoor $\mathrm{HCl}$ levels.

\section{Key Words}

cavity ring-down spectroscopy, real-time measurements, reactive chlorine, bleach, cooking, hydrochloric acid

\section{Practical Implications}

Despite extensive research in outdoor atmospheres, hydrogen chloride $(\mathrm{HCl})$ has not been well studied indoors. These are the first real-time measurements of indoor $\mathrm{HCl}$. They were made using a portable, quiet, and fast spectrometric instrument that allowed sampling to occur in a 
private, occupied dwelling. The use of this instrument allows for $\mathrm{HCl}$ source elucidation during typical household activities. Occupants maintained a detailed activity log, which allowed for sources to be determined. We show that activities such as cleaning with bleach, chlorinated dishwasher detergent use and cooking lead to increased $\mathrm{HCl}$ levels, with implications for potential oxidation chemistry in the indoor air environment.

\section{Introduction}

Resulting from direct emission and secondary production, $\mathrm{HCl}$ has been known to be present in the atmosphere at detectable levels for the past several decades. ${ }^{1-15}$ Processes such as volcanic eruptions, biomass burning, coal combustion and waste incineration emit $\mathrm{HCl}$ directly. ${ }^{7,15}$ Secondary formation of $\mathrm{HCl}$ is facilitated by reactions on chloride-containing aerosols. $^{2,15,16}$ Although the subject of numerous atmospheric measurements and modelling studies, these sources are not well constrained. In indoor environments sources of $\mathrm{HCl}$ are unknown despite knowledge that harmful $\mathrm{HCl}$ exposure may occur via inhalation and direct contact. ${ }^{17}$ Like other strong acids, $\mathrm{HCl}$ exposure causes irritation of respiratory tract, eyes, and skin. ${ }^{17}$ While these effects occur when $\mathrm{HCl}$ levels reach 5 parts per million by volume (ppmv), the impact of chronic exposure to low-level $\mathrm{HCl}$ (i.e. parts per billion to parts per trillion by volume) is not known. In addition, strong acids such as $\mathrm{HCl}$ can corrode metals such as those in electronic devices ${ }^{18}$ and damage works of art. ${ }^{19}$

The lifetime of trace atmospheric pollutants is governed by oxidative chemistry in the troposphere. ${ }^{20,21}$ Principal tropospheric oxidants include hydroxyl radicals and chlorine atoms. ${ }^{20}$ Recent work has shown that chlorine atoms oxidize volatile organic compounds (VOCs) and produce ozone more efficiently than hydroxyl radicals, even in small quantities. ${ }^{22}$ Chlorine atoms 
also contribute to destruction of polar boundary layer ozone via a halogen catalyzed ozone destruction cycle. ${ }^{23}$ Both scenarios have significant air quality and environmental implications, thus monitoring of chlorine atoms is essential. Yet, due to the highly reactive nature of chlorine atoms, direct measurement techniques do not exist. ${ }^{24}$ Because of this, chlorine atom precursors are used as proxies to understand chlorine atom chemistry in the troposphere. Precursors include molecular chlorine $\left(\mathrm{Cl}_{2}\right)$, nitryl chloride $\left(\mathrm{ClNO}_{2}\right)$, hypochlorous acid $(\mathrm{HOCl})$, and $\mathrm{HCl}(\mathrm{R} 1-$ R4). ${ }^{2,21,25-28}$

$$
\begin{aligned}
& \mathrm{Cl}_{2}+h v \rightarrow \mathrm{Cl} \cdot+\mathrm{Cl} \cdot \\
& \mathrm{ClNO}_{2}+h v \rightarrow \mathrm{Cl} \cdot+\mathrm{NO}_{2} \\
& \mathrm{HOCl}+h v \rightarrow \mathrm{Cl} \cdot+\mathrm{HO} . \\
& \mathrm{HCl}+\mathrm{HO} \cdot \rightarrow \mathrm{Cl} \cdot+\mathrm{H}_{2} \mathrm{O}
\end{aligned}
$$

Production of chlorine atoms results from photolysis and oxidation reactions of precursor molecules. Chlorine atoms abstract hydrogen rapidly with VOCs:

$$
\mathrm{Cl} \cdot(g)+\mathrm{RH}_{(g)} \rightarrow \mathrm{HCl}_{(g)}+\mathrm{R} \cdot(g)
$$

where RH represents any VOC. ${ }^{2,15}$ Due to the large relative abundance of reactants in polluted coastal regions, the reaction proceeds with ease. ${ }^{14}$ It is possible that analogous reactions could occur in the indoor environment.

Emission of reactive chlorine species to indoor air occurs through a wide variety of typical household tasks. Recently Wong et al. ${ }^{29}$ demonstrated that reactive chlorine in the form of $\mathrm{HOCl}, \mathrm{Cl}_{2}$, and $\mathrm{ClNO}_{2}$ is emitted during floor cleaning with chlorine bleach. Cleaning floors with bleach is a method that has been used for decades to disinfect and remove stains and is relatively cost effective compared to other cleaners. Many recognize bleach by its characteristic scent, which can be overwhelming and lead to side effects such as dizziness and headaches. 
These reactive chlorine observations, along with the ubiquity of bleach in households globally, demonstrates that further investigation of reactive chlorine emissions indoors is necessary. Unlike the reactive species discussed by Wong et al., sources and human health impacts of traditional water disinfection byproducts (DBPs) indoors has been studied extensively. ${ }^{30-34}$ The most commonly studied DBPs, trihalomethanes (THMs) and haloacetic acids (HAAs), can enter indoor air via washing machines, showers, dishwashers and taps. ${ }^{29,30}$ This emission is dependent on the concentration of chlorine and DBPs present in municipal drinking water. One region in particular that relies heavily on chlorination for water disinfection is Newfoundland and Labrador. In this province, many communities have elevated chlorine levels, which sometimes can exceed the national average tenfold. ${ }^{35,36}$ Because of this, it might be expected that exposure to reactive chlorine species is elevated throughout the province. These levels may be further increased when chlorinated detergents are used for washing dishes and clothing. Thus, indoor reactive chlorine exposure may not be limited to only THMs and HAAs from drinking water. Due to the lack of measurements, it is important to begin identifying reactive chlorine species and their sources in private dwellings. In this work, the reactive chlorine species $\mathrm{HCl}$ is measured for the first time to enhance understanding of chlorine chemistry and sources indoors. Measurements were collected using a $\mathrm{HCl}$ cavity ring-down spectrophotometer (CRDS). Using the CRDS, we provide: i) the first high-time resolution measurements of indoor $\mathrm{HCl}$; and ii) preliminary estimates of $\mathrm{HCl}$ emissions from typical household activities such as cleaning and cooking. 


\section{Methods}

Measurements via Cavity Ring-Down Spectroscopy

All measurements were performed using a CRDS (G2108 Hydrogen Chloride Analyzer from Picarro, Inc.). This specific model detects trace gaseous $\mathrm{HCl}$, with no interference from other gaseous species such as $\mathrm{HOCl}$, by using a high precision distributed feedback laser centered at $5739.2625 \mathrm{~cm}^{-1} \cdot{ }^{37}$ The Picarro analyzer contains a heated $\left(70.000 \pm 0.005{ }^{\circ} \mathrm{C}\right)$, low-pressure $(0.1842 \pm 0.0002 \mathrm{~atm})$ high finesse optical cavity, which has three high reflectivity mirrors, two flat and one curved. ${ }^{38}$ The total reflectance capability is the magnitude of signal loss in the empty optical cavity, which is less than $50 \mathrm{ppm}$ for this design, leads to a limit of detection of 84 partsper-trillion by volume (pptv) measured over $5 \mathrm{~min}$ in zero air at $0 \%$ relative humidity (RH). Under the same conditions, the precision $(1 \sigma)$ of the instrument was determined to be $\pm 24 \mathrm{pptv}$ in 5 min. The $\mathrm{HCl}$ CRDS is an ideal instrument for sampling indoors because it is portable (31.75 kg), quiet (40 dB), does not require consumables (e.g. compressed gas cylinders) nor frequent calibration. ${ }^{39}$

\section{Indoor Air Sampling}

Sampling occurred in a private dwelling located in St. John's, Newfoundland and Labrador from April 17 to May 24, 2017. Mixing ratios of $\mathrm{HCl}$ were monitored during the operation of two household appliances: a dishwasher and electrically-heated ceramic stovetop. Mixing ratios were also monitored while cleaning the kitchen and dining room floors with bleach. The CRDS was placed on the kitchen counter above the dishwasher for all experimental work, approximately 36 inches above the floor. The inlet, an 8 " length of 1/4" perfluoroalkoxy (PFA) tubing, was directed towards the stovetop and parallel to the floor and had a $75 \mathrm{~ms}$ residence time. Air was sampled at a rate of 2 SLPM. Submicron pre-filter and back-up filter are present inside the $\mathrm{HCl}$ analyzer and remove particles entrained in the sample flow prior to the 
sample gases entering the optical cavity. We performed laboratory validations of the system using $\mathrm{HCl}$ delivered from a permeation tube (see section $\mathrm{S} 1$ for more information). By collecting the output of the permeation tube into a bubbler $(1 \mathrm{mM} \mathrm{KOH})$ and analyzing the extract by ion chromatography coupled to conductivity detection, the permeation tube output was determined as $140 \pm 18 \mathrm{ng} \min ^{-1}(\mathrm{n}=3)$. The permeation tube output was measured by the CRDS through an inlet with a $79 \mathrm{~ms}$ residence time. Measurements were made at 0,20 , and $50 \% \mathrm{RH}$, which encompass typical RH conditions indoors. The CRDS and offline IC measurements agreed within error. Response times (1/e) determined from full signal decays under the three RH conditions ranged from 26 to $32 \mathrm{~s}$. The room in which the measurements were made had a volume of approximately $71 \mathrm{~m}^{3}$ within a 1.5 story $220 \mathrm{~m}^{2}$ home. The doors in the room were left open while measurements were taken, allowing for inter-room air transport. The air exchange rate for the sampling site was not measured for this campaign, but has been estimated to be $0.1 \mathrm{~h}^{-1}$ (see Section S2 in the SI) ${ }^{40,41}$ Background measurements of $\mathrm{HCl}$ were taken during a 12-hour period prior to bleach cleaning and cooking experiments. Ambient levels ranged from $0.21-0.31 \mathrm{ppbv}$ and remained relatively constant despite changes in solar radiation and temperature (Figure S1).

\section{Bleach Cleaning Experiments}

In order to approximate household reactive chlorine emissions while cleaning with bleach, a bottle of commercially available bleach was purchased and diluted as per the manufacturer's instructions. The diluted bleach solution was applied to a $12 \mathrm{~m}^{2}$ section of hardwood flooring over a span of 3-4 minutes. After application, the bleach cleaning solution was moved outdoors to ensure that its emissions did not interfere with the emission measurement from the floor surface. The floor was allowed to dry with minimal disturbance. Two subsequent applications on the same surface were performed using the same technique immediately after the floor had dried and the $\mathrm{HCl}$ mixing ratio had decayed to near its initial mixing ratio. All bleach 
applications were performed after sunset. Lights in the test room were turned on for the duration of the experiment, which was equipped with a combination of light-emitting diode (LED), halogen-tungsten, and covered fluorescent tube light sources.

\section{Dishwashing Experiments}

The CRDS was placed within $50 \mathrm{~cm}$ of the vent from the dishwasher and various dishwashing scenarios were explored. To investigate detergent composition effects on indoor $\mathrm{HCl}$ mixing ratios, organo-chlorine, bleach, and non-chlorinated detergents were used in the dishwasher. All experiments used the normal wash cycle of a Frigidaire dishwasher. The normal cycle uses $23 \mathrm{~L}$ of water over a span of 2 washes and 3 rinses. The drying cycle occurs after the 89 minute-long wash cycle. Dishwasher experiments were performed after sunset or just after sunrise. Lights in the room (LED, halogen-tungsten, and covered fluorescent) were turned on.

\section{Cooking Experiments}

The CRDS inlet was placed $2.5 \mathrm{~m}$ away from a stovetop. Mixing ratios of $\mathrm{HCl}$ were measured during stovetop cooking using a Frigidaire electric range with ceramic cooktop. The occupants consumed only a plant-based diet during these measurements, and therefore meals included vegetables, seasonings and oils. Cooking occurred mid-day, thus the room was illuminated by a combination of ambient sunlight, LED, halogen-tungsten, and covered fluorescent lights during the experiment.

\section{Cl Production Rate Constant Calculations}

Measurements of wavelength-resolved photon fluxes for common indoor light sources were made by Kowal and Kahan. ${ }^{42}$ Measured photon fluxes were used to calculate photolysis rate constants $(J)$ for chlorine atom precursors $\mathrm{Cl}_{2}, \mathrm{HOCl}$, and $\mathrm{ClNO}_{2}$ using

$$
J=\int_{\lambda_{i}}^{\lambda_{f}} \sigma(\lambda) \varphi(\lambda) F_{\lambda} d \lambda
$$


where $\lambda, \sigma, \varphi$ represent the wavelength, absorption cross-section of the molecule, and photolysis quantum yield, respectively. Absorption cross sections were taken from Maric et al. ${ }^{43}\left(\mathrm{Cl}_{2}\right)$, Barnes et al. ${ }^{44}(\mathrm{HOCl})$, and Ghosh et al. ${ }^{45}\left(\mathrm{ClNO}_{2}\right)$. Quantum yields of 1 were used for $\mathrm{Cl}_{2}$ and $\mathrm{HOCl},{ }^{46}$ while a quantum yield of 0.93 was used for $\mathrm{ClNO}_{2 .}{ }^{47}$ Radical $(\mathrm{OH}$ or $\mathrm{Cl})$ production rates were calculated as the product of the photolysis rate constant and the expected concentration of the precursor following bleaching events.

\section{Results/Discussion}

\section{Cleaning Experiments}

Elevated $\mathrm{HCl}$ mixing ratios relative to background levels were observed following each of three consecutive bleach applications (Figure 1).

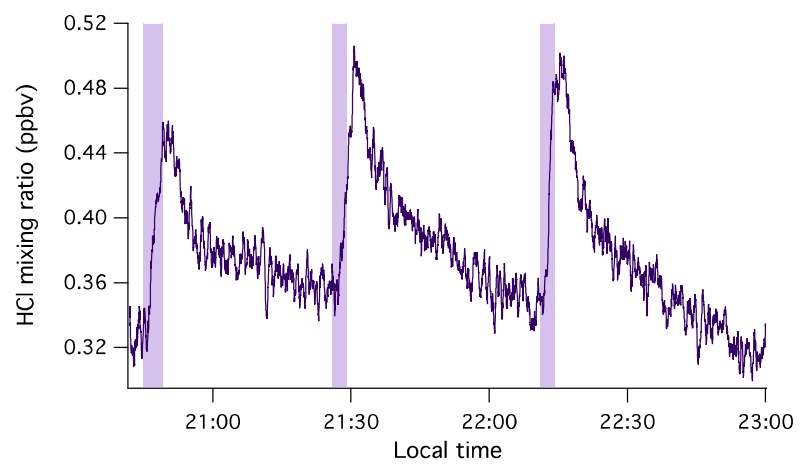

Figure 1. $\mathrm{HCl}$ mixing ratios measured during three sequential bleach applications. Measurements are presented as the 30 -second average of the $\mathrm{HCl}$ mixing ratio in parts-per-billion by volume (ppbv). Bleaching applications spanning $3 \pm 1$ minute periods are represented by the shaded regions, and the $\mathrm{HCl}$ mixing ratio by the solid line.

All bleach applications showed similar changes in $\mathrm{HCl}$ mixing ratios above the background, indicating that the magnitude of the emission is reproducible. With each application, an initial spike of approximately $0.1 \mathrm{ppbv}$ occurred and was followed by a slower decay (Figure 2). 


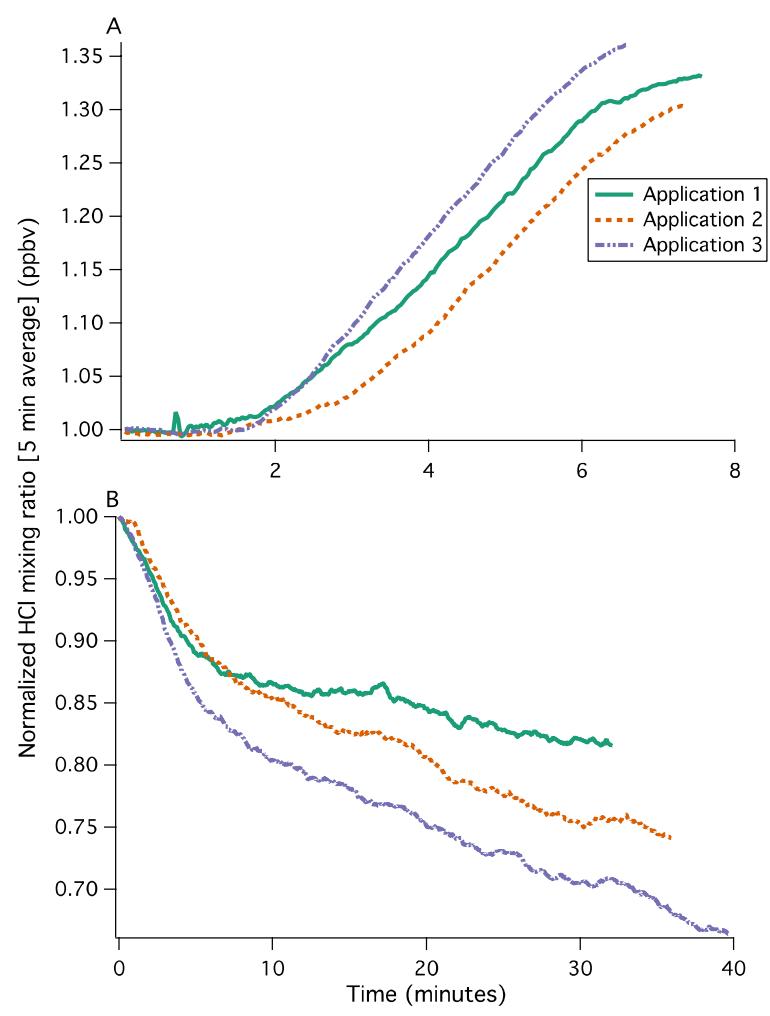

Figure 2. (A) Rise and (B) decay in $\mathrm{HCl}$ mixing ratio after bleach applications. Results from this experiment are presented normalized to the background (A) or maximum (B) concentration. In all cases, the measurements are the 5-minute average $\mathrm{HCl}$ mixing ratio in parts-per-billion by volume (ppbv).

Prior to bleach application, mixing ratios ranged from $0.32-0.36 \mathrm{ppbv}$ and in less than ten minutes, mixing ratios increased to $0.43-0.48 \mathrm{ppbv}$. Over about thirty minutes, the mixing ratio returned to initial conditions. Both figures $2 \mathrm{~A}$ and $\mathrm{B}$ show that the rise and decay for $\mathrm{HCl}$ is reproducible in all three trials. After 30 minutes, $\mathrm{HCl}$ mixing ratios had decayed by $52-62 \%$ of peak levels observed during the bleaching event. The emission trends observed for $\mathrm{HCl}$ resemble those of gaseous $\mathrm{HOCl}$ and $\mathrm{Cl}_{2}$ reported by Wong et al. ${ }^{29}$ From this data, we cannot determine whether $\mathrm{HCl}$ is emitted directly or formed indirectly. It is possible that photolysis could aid in the indirect formation of $\mathrm{HCl}$. A previous study ${ }^{29}$ has shown that $\mathrm{HOCl}, \mathrm{Cl}_{2}$ and $\mathrm{ClNO}_{2}$ are released 
during floor mopping with bleach. All three are known to photolyze under ambient outdoor light to produce $\mathrm{Cl}$ atoms (e.g. ${ }^{22,24,27}$ ) which react with VOCs to form $\mathrm{HCl}$ (Figure 3). ${ }^{29,48}$

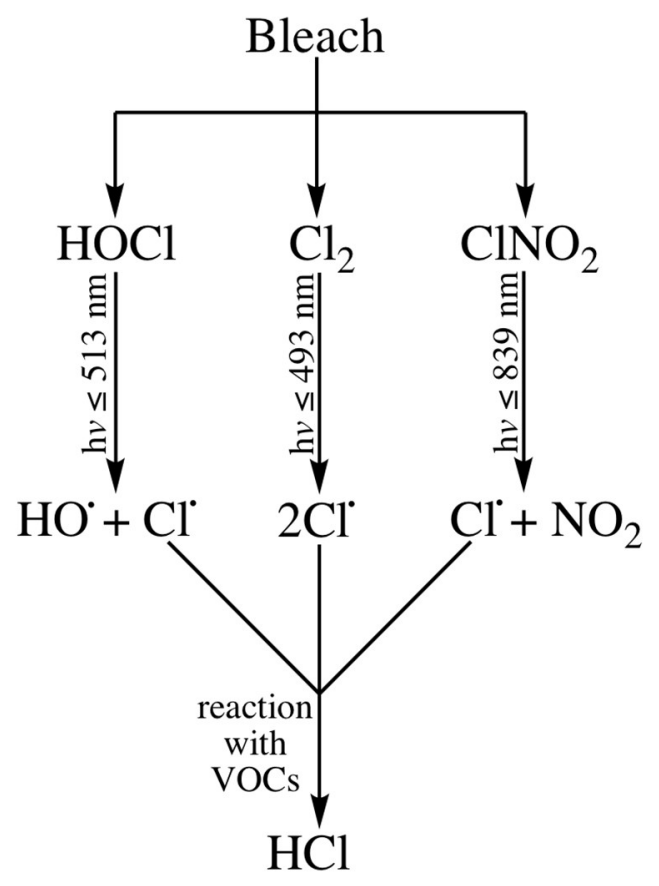

Figure 3. Proposed reaction pathway for indirect formation of $\mathrm{HCl}$ via photolysis of $\mathrm{HOCl}, \mathrm{Cl}_{2}$, and $\mathrm{ClNO}_{2}$ emitted from bleach use.

This work was performed under artificial lighting, consisting of LED, halogen-tungsten, and covered fluorescent tubes, which emit at wavelengths longer than 400, 308, and $363 \mathrm{~nm}$, respectively. ${ }^{42}$ Under these light conditions, photolysis reactions shown in Figure 3 could proceed. Calculated $\mathrm{Cl}$ photolysis production rates under illumination by various light sources at $\mathrm{Cl}_{2}$ and $\mathrm{HOCl}$ mixing ratios reported after the use of bleach (20 ppbv and $\left.200 \mathrm{ppbv}\right)$, and at an estimated $\mathrm{ClNO}_{2}$ mixing ratio of $1 \mathrm{ppbv}$ are shown in Table 1 and Table $\mathrm{S} 4 .^{29,42}$ The $\mathrm{Cl}$ production rate at the light source represents the maximum production rate, while that at $1 \mathrm{~m}$ from the light source is the production expected at approximately human head height. Photolysis rate constants for all three species can be found in the SI. Cl atoms are predicted to be formed from $\mathrm{Cl}_{2}$ photolysis at rates on the order of $0.1-1.2 \times 10^{8}$ molec $\mathrm{cm}^{-3} \mathrm{~s}^{-1}$ under illumination by 
the LED, halogen-tungsten, and covered fluorescent tubes used in the residence, while formation rates from $\mathrm{HOCl}$ photolysis will range from $0.2-5.9 \times 10^{7}$ molec $\mathrm{cm}^{-3} \mathrm{~s}^{-1}$ under the same illumination conditions. Production rates of $\mathrm{Cl}$ from $\mathrm{ClNO}_{2}$ photolysis will not exceed $3 \times 10^{5}$ molec $\mathrm{cm}^{-3} \mathrm{~s}^{-1}$ under these conditions. However, it should be reiterated that $\mathrm{ClNO}_{2}$ mixing ratios after the use of bleach have not been quantified. ${ }^{29}$ If mixing ratios are significantly larger than the 1 ppbv used in these calculations, it could be an important photochemical $\mathrm{Cl}$ source. Assuming the same lamp power, halogen-tungsten lamps will generate the most radicals for each $\mathrm{Cl}$ precursor. The $\mathrm{Cl}$ production rates listed above were calculated based on photon fluxes measured directly adjacent to the light sources. At a distance of $1 \mathrm{~m}$ away from the light sources, the rates will decrease to $0.5-2.6 \times 10^{6}$ molec cm $\mathrm{cm}^{-3} \mathrm{~s}^{-1}$ for $\mathrm{Cl}_{2}, 0.3-13 \times 10^{5} \mathrm{molec} \mathrm{cm}^{-3} \mathrm{~s}^{-1}$ for $\mathrm{HOCl}$, and $0.2-6.5 \times 10^{3}$ molec $\mathrm{cm}^{-3} \mathrm{~s}^{-1}$ for $\mathrm{ClNO}_{2}$. For context, $\mathrm{OH}$ production rates indoors (formed from dark reactions between ozone and alkenes and from HONO photolysis) are expected to be on the order of $10^{7}$ molec $\mathrm{cm}^{-3} \mathrm{~s}^{-1}$ in residences. ${ }^{42,49,50}$ Photochemical $\mathrm{Cl}$ production rates during the use of bleach may therefore exceed $\mathrm{OH}$ production rates under some conditions. Potential photochemical $\mathrm{Cl}$ production rates from light sources not present in the residence during the experiments (including sunlight) are provided in the SI.

The measured $\mathrm{HCl}$ production rate during the bleaching experiments was $\sim 1.2 \times 10^{7}$ molec $\mathrm{cm}^{-3} \mathrm{~s}^{-1}$. This is similar to photochemical $\mathrm{Cl}$ production rates predicted in Table 1 ; since $\mathrm{Cl}$ reacts at near diffusion-limited rates with many VOCs, photochemical generation of $\mathrm{Cl}$ is expected to be the rate-limiting step. This suggests that at least some of the detected $\mathrm{HCl}$ may be formed from photolysis of $\mathrm{Cl}_{2}$ and $\mathrm{HOCl}$, rather than direct emission from the bleach solution. $\mathrm{HCl}$ and photolabile chlorine species have not been measured simultaneously indoors after the use of bleach; however, this would be necessary to determine the source of the $\mathrm{HCl}$ with a high degree of certainty. 
Table 1. Calculated $\mathrm{Cl}$ production rates for light sources in this study for $20 \mathrm{ppbv} \mathrm{Cl}_{2}, 200 \mathrm{ppbv} \mathrm{HOCl}$, and $1 \mathrm{ppbv} \mathrm{ClNO}_{2}$ at $1 \mathrm{~m}$ from the light source. Mixing ratios were based on measurements from Wong et al. $^{27}$

\begin{tabular}{|c|c|c|c|}
\hline \multirow[b]{2}{*}{ Light source } & \multicolumn{3}{|c|}{ Cl Production Rate (molecules $\mathrm{cm}^{-3} \mathrm{~s}^{-1}$ ) } \\
\hline & $\mathrm{Cl}_{2}$ & $\mathrm{HOCl}$ & $\mathrm{ClNO}_{2}$ \\
\hline LED & $4.62 \times 10^{5}$ & $3.26 \times 10^{4}$ & $2.17 \times 10^{2}$ \\
\hline Halogen & $2.56 \times 10^{6}$ & $1.30 \times 10^{6}$ & $6.50 \times 10^{3}$ \\
\hline $\begin{array}{l}\text { Office fluorescent } \\
\text { (covered) }\end{array}$ & $1.45 \times 10^{6}$ & $4.26 \times 10^{5}$ & $1.20 \times 10^{3}$ \\
\hline
\end{tabular}

The bimodal decay observed in Figure $2 \mathrm{~B}$ is likely attributed to $\mathrm{HCl}$ deposition to surfaces, and environmental factors (e.g. temperature and air-exchange rate). Weschler and Nazaroff have recently shown that initially, some semi-volatile organic compounds adsorb to surfaces indoors. ${ }^{51}$ This adsorption will result in the formation of an organic film on the surface, which can then absorb additional settling species. Since $\mathrm{HCl}$ readily deposits to all outdoor surfaces (e.g. Crisp et al. ${ }^{15}$ ), we expect the same to occur indoors. The abundance of surfaces present in the experimental kitchen participates in the emission and decay of $\mathrm{HCl}$. After emissions cease, these will approach a state of thermodynamic equilibrium that depends on surface properties, temperature, and relative humidity in the indoor environment. Since the dwelling has radiative heat rather than forced air, the measurement background is not likely affected much by the air exchange rate $\left(\sim 0.1 \mathrm{~h}^{-1}\right) .{ }^{40,41}$

\section{Dishwashing Experiments}

Previous studies have shown that dishwashers emit compounds including chlorinated organics, which are released when chlorinated dishwashing detergents are used. ${ }^{31}$ Emissions from the experimental dishwasher were monitored during four different conditions: (1) no detergent; (2) powdered organo-chlorine detergent; (3) liquid bleach detergent; and (4) non-chlorinated 
detergent. All experiments were conducted in the absence of dishes. In condition (1), a dishwasher cycle was started to establish a baseline and determine whether the water alone contributed to $\mathrm{HCl}$ emissions. Since Newfoundland is known for elevated chlorination rates, it was essential to determine whether the water itself contributed to indoor $\mathrm{HCl}$ levels before assessing the effects of chlorinated detergents. ${ }^{35,36}$ A stable signal was observed before, throughout and after the cycle, confirming that household $\mathrm{HCl}$ emissions did not result from tap water. In conditions (2) and (3) with chlorinated detergents, emission of $\mathrm{HCl}$ was observed in all experiments $(n=4)$ (Table 2, Figure 4).

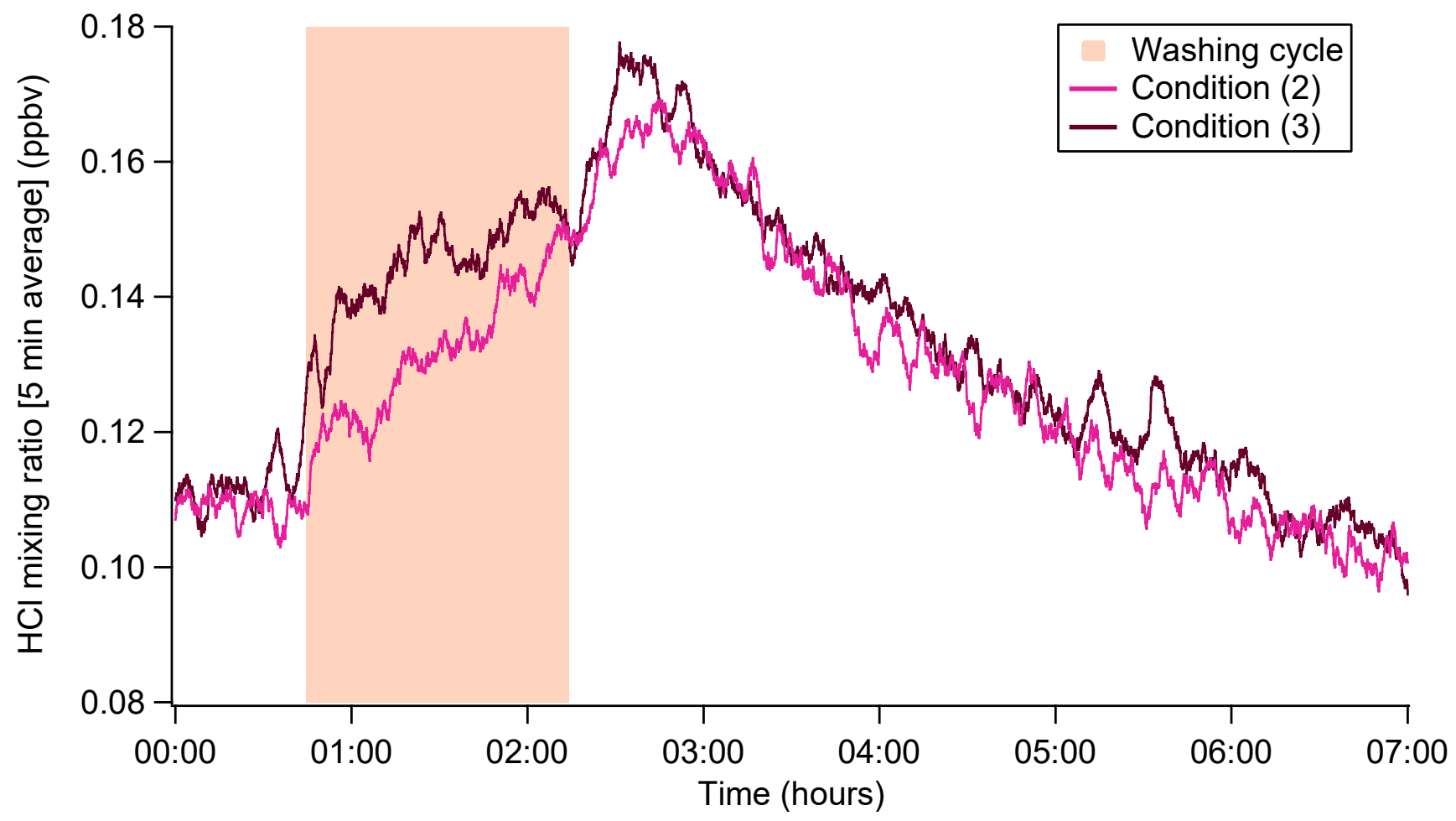

Figure 4. $\mathrm{HCl}$ mixing ratio during a condition (2) and (3) dishwashing scenario. In both cases, the measurements are the 5-minute average $\mathrm{HCl}$ mixing ratio in parts-per-billion by volume (ppbv).

Both organo-chlorine and bleach detergents showed similar emissions of $\mathrm{HCl}$ when used in the empty dishwasher (example shown in Figure 4). There was an initial spike in emissions at the beginning of the cycle, followed by a gradual, yet consistent, increase in $\mathrm{HCl}$ mixing ratio. Once 
the cycle ended, $\mathrm{HCl}$ levels increased. This is attributed to the dishwasher drying cycle (mixing ratio increase observed following the shaded area on Figure 4), which evaporates the solution contents of the dishwasher into its headspace and into the kitchen via vents located on the dishwasher door. After the drying cycle ended, the $\mathrm{HCl}$ mixing ratio began a slow, constant decay. Similar to cleaning experiments, $\mathrm{HCl}$ decayed after dishwashing experiments by double exponential. Comparison between all dishwashing conditions was not possible because of the different environmental factors (e.g. temperature) between conditions.

Table 2. Mixing ratio increases relative to initial background conditions observed during dishwashing experiments.

\begin{tabular}{ccccc} 
& & \multicolumn{3}{c}{ HCl mixing ratio (pptv) [5 min avg] } \\
\cline { 3 - 5 } Condition & Detergent Type & Background & Increase with cycle & Increase with drying \\
\hline \hline 2 & Organo-chlorine & 190 & 22 & 33 \\
\hline 2 & Organo-chlorine & 130 & 23 & 50 \\
\hline \hline 3 & Bleach & 110 & 40 & 59 \\
\hline \hline 3 & Bleach & 100 & 50 & 65 \\
\hline \hline & Non-chlorinated & 180 & 0 & -9.8 \\
\hline & & Average increase (2) & 22 & 41 \\
\cline { 3 - 5 } & & Average increase (3) & 45 & 62 \\
\cline { 3 - 5 } & & &
\end{tabular}

When chlorinated detergents are used, the $\mathrm{HCl}$ mixing ratio increases with both washing and drying cycles. The maximum average mixing ratio increase from the beginning of the cycle was 22 and 45 pptv due to conditions 2 and 3, respectively. Emissions from the drying cycle further contribute to mixing ratios, as $\mathrm{HCl}$ levels undergo an additional increase of 17 to $19 \mathrm{pptv}$. From results of conditions 2 and 3, we observe that detergent choice can influence the extent of $\mathrm{HCl}$ release indoors. To further confirm the influence of chlorinated detergents on $\mathrm{HCl}$ emissions, the experiment was replicated using detergents free of chlorine. No differences in $\mathrm{HCl}$ mixing ratios were observed during dishwashing with this type of detergent. The observed $\mathrm{HCl}$ mixing ratio 
increase as a result of dishwashing using chlorinated detergents was approximately twenty times less than from surface bleach application. There is currently no information regarding emissions of photolabile chlorine species (e.g. $\mathrm{Cl}_{2}$ ) from dishwashers. If reactive chlorine species are being emitted from dishwashers, the $\mathrm{HCl}$ measured could be formed indirectly in addition to direct emission. In all dishwasher experiments the $\mathrm{HCl}$ signal decays to values less than initial conditions. This can be attributed to the home cooling during the day, as dictated by the temperature program (see Table S1 in the SI). Depletion of $\mathrm{HCl}$ can also be a result of household air exchange rates over the course of the experiment, which spanned several hours. ${ }^{41}$ Since parameters such as photon flux and ventilation rate were not measured, it is difficult to determine a definitive sink of $\mathrm{HCl}$ in this case.

It is likely that food residue in the dishwasher would further affect the emissions. Olson and Corsi analyzed emissions of THMs from dishwashers with soiled dishes, which demonstrated that food residues has an impact on emissions depending on type, storage method, and age. ${ }^{31}$ For example, it was demonstrated that meat protein and acidic fruits and vegetables would increase emissions, whereas food storage techniques such as freezing may impact the integrity of the protein and reduce emissions. In order to determine whether or not food residues contribute to indoor $\mathrm{HCl}$ levels, further studies that investigate a wide variety of food types are recommended.

\section{Cooking Experiments}

We observed emissions of $\mathrm{HCl}$ from frying pan use on an electric stovetop. Since electric appliances require electricity instead of combustion for heat generation, emissions from the stovetop itself are considered negligible. This indicates that food must be the source of $\mathrm{HCl}$ while cooking. This is unsurprising, since smoldering-stage biomass burning, a well-known source of gaseous $\mathrm{HCl}$, is a similar physical transformation to cooking. ${ }^{52}$ An example of cooking, showing two events, is presented in Figure 5. 


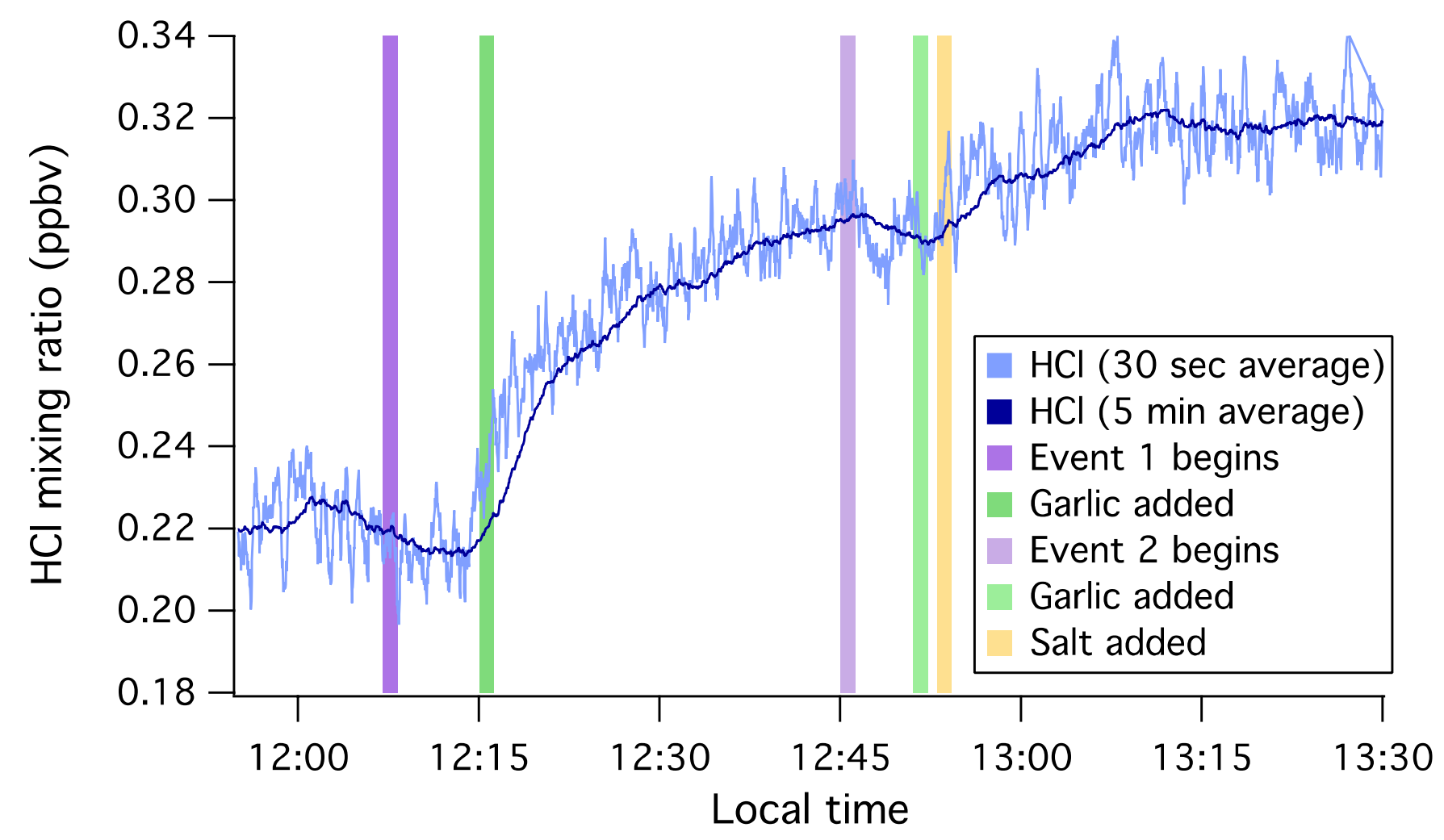

Figure 5. $\mathrm{HCl}$ mixing ratio during two consecutive cooking experiments. Commencement of cooking, and garlic and salt addition are indicated by shaded regions. $\mathrm{HCl}$ mixing ratios are presented by 30 -second and 5-minute averages in ppbv.

Cooking event 1 began by adding onions to a pan containing pre-heated vegetable oil. The kitchen $\mathrm{HCl}$ mixing ratio remained relatively constant at $220 \mathrm{pptv}$. The addition of fresh chopped garlic, followed by the addition of other ingredients 3 min later resulted in a $81 \mathrm{pptv}$ increase over approximately $30 \mathrm{~min}$. Other ingredients in event 1 included water, rice, parsley, vegetable bouillon (no $\mathrm{NaCl}$ or $\mathrm{KCl}$ added), onions, and lettuce. At 16:15, event 2 began. Again, the addition of fresh chopped garlic coincided with the start of a 28 pptv mixing ratio increase over a period of 30 minutes. Other ingredients used in event 2 included salt, curry powder, rice, vegetable bouillon, shallots, and zucchini. 
Similar to observations of burning vegetation that have experienced sea salt deposition ${ }^{52}$, cooking with table salt will likely increase emissions of $\mathrm{HCl}$. The addition of table salt in cooking may be expected to increase $\mathrm{HCl}$ emissions. A slight increase in mixing ratios is coincident with salt addition in event 2 . In both cooking events, it is interesting to note that the mixing ratio increased as the components in the pan began to brown, and as fresh garlic was added. It is possible that $\mathrm{HCl}$ is emitted when these vegetables, among others, cook or burn. Many vegetables and fruits contain chlorine in the form of chloride. ${ }^{53,54}$ On a cellular level chloride is required for stomatal opening when guard cells cannot synthesize malate. ${ }^{54,55}$ Levels of chloride depend on species, but also on the location and conditions under which the food was grown. ${ }^{52,53}$ For example, food cultivated in close proximity to the ocean may have enhanced chlorine levels because of sea salt deposition and uptake. ${ }^{52}$ Onions and garlic, which belong to the same family (allium) as shallots, have been shown to contain chloride. ${ }^{53,54}$ Thus it is likely that direct emission via plant species contributes to $\mathrm{HCl}$ mixing ratios while cooking. Additional investigation is required to further elucidate $\mathrm{HCl}$ sources from cooking, by both accurate measurement of food and cooking food individually.

\section{Instrumentation for Indoor Measurement of $\mathrm{HCl}$}

Since regular measurement of $\mathrm{HCl}$ has not yet been established for indoor environments, existing techniques must be evaluated for use indoors. The most common technique for $\mathrm{HCl}$ measurement outdoors is the annular denuder system (ADS), which is comprised of a sintered glass rod, a back-up filter and a vacuum pump. ${ }^{4-6,956}$ Sampling with an ADS occurs over the timescale of hours, providing one collective sample. Since $\mathrm{HCl}$ partitions rapidly from the gas to particle phase or deposits on surfaces, accurate measurements in real-time are essential. ${ }^{52}$ This requirement is satisfied when high time-response measurements of $\mathrm{HCl}$ are acquired with chemical ionization mass spectrometry (CIMS). ${ }^{15,57}$ While useful for outdoor measurements, 
CIMS is not ideal for use in private dwellings. It has a large footprint, substantial power draw, several vacuum pumps, and most require a radioactive ionization source. ${ }^{57}$ Ideal analysis for $\mathrm{HCl}$ indoors would provide sensitive, real-time, fast measurements with a safe and easily transportable instrument. This work demonstrates the first use of a compact, quiet, and energy-conservative CRDS instrument suitable for in-situ $\mathrm{HCl}$ measurements indoors.

\section{Conclusions}

Daily household activities were investigated to determine their contribution to indoor $\mathrm{HCl}$ emissions. Measurements were made using an in situ, non-invasive, fast time-response CRDS instrument. These represent the first fast-time response measurements of $\mathrm{HCl}$ in an indoor, nonoccupational setting and can be used to identify $\mathrm{HCl}$ sources indoors. Surface cleaning and disinfecting using bleach has been found as a source for $\mathrm{HCl}$. Chlorinated dishwasher detergents directly impact household $\mathrm{HCl}$ levels, whereas non-chlorinated detergents have no impact. Additionally, the dishwasher drying cycle has a noteworthy impact on already-elevated $\mathrm{HCl}$ mixing ratios. Photolysis of photolabile chlorine species (e.g. $\left.\mathrm{Cl}_{2}\right)$, leading to formation of $\mathrm{HCl}$, is possible under indoor conditions, but more work is needed to determine whether bleach cleaning and dishwashing sources of $\mathrm{HCl}$ are direct or indirect. Cooking vegetables resulted in emissions of $\mathrm{HCl}$. Sources of $\mathrm{HCl}$ in these vegetables can result from chlorine contained within the plant cells, as well as heterogeneous reactions. The findings of this work have enhanced understanding of reactive chlorine chemistry indoors. Despite an advance in knowledge, additional work is required to determine a complete inventory of reactive species and their chemistry to determine how they impact indoor air quality and hence human health. 


\section{Acknowledgements}

We thank the Natural Science and Engineering Research Council of Canada, Memorial University, and Syracuse University for funding. 


\section{References}

(1) Rahn, KA, Borys, RD, Butler, EL, Duce, RA Gaseous and particulate halogens in the New York City atmosphere. Ann N Y Acad Sci. 1979;322:143-151.

(2) Graedel, TE, Keene, WC Tropospheric budget of reactive chlorine. Global Biogeochem Cycles. 1995;9:47-77.

(3) Gounon, J, Milhau, A Analysis of inorganic pollutants emitted by the City of Paris garbage incineration plants. Waste Manag Res. 1986;4:95-104.

(4) Johnson, CA, Sigg, L, Zobrist, J Case studies on the chemical composition of fogwater: The influence of local gaseous emissions. Atmos Environ. 1987;21:2365-2374.

(5) Keuken, MP, Schoonebeek, CAM, van Wensveen-Louter, A, Slanina, J Simultaneous sampling of $\mathrm{NH} 3, \mathrm{HNO} 3, \mathrm{HC} 1, \mathrm{SO} 2$ and $\mathrm{H} 2 \mathrm{O} 2$ in ambient air by a wet annular denuder system. Atmos Environ. 1988;22:2541-2548.

(6) Matsumoto, M, Okita, T Long term measurements of atmospheric gaseous and aerosol species using an annular denuder system in Nara, Japan. Atmos Environ. 1998;32:14191425.

(7) Keene, WC, Khalil, MAK, Erickson, DJ, McCulloch, A, Graedel, TE, Lobert, JM, Aucott, ML, Gong, SL, Harper, DB, Kleiman, G, et al. Composite global emissions of reactive chlorine from anthropogenic and natural sources: Reactive chlorine emissions inventory. $J$ Geophys Res. 1999;104:8429-8440.

(8) Jourdain, B, Legrand, M Year-round records of bulk and size-segregated aerosol composition and $\mathrm{HCl}$ and $\mathrm{HNO} 3$ levels in the Dumont d'Urville (coastal Antarctica) atmosphere: Implications for sea-salt aerosol fractionation in the winter and summer. $J$ Geophys Res Atmos. 2002;107:1-13.

(9) Bari, A, Ferraro, V, Wilson, LR, Luttinger, D, Husain, L Measurements of gaseous HONO, HNO3, SO2, HCl, NH3, particulate sulfate and PM2.5 in New York, NY. Atmos Environ. 2003;37:2825-2835.

(10) Keene, WC, Pszenny, AAP, Maben, JR, Stevenson, E, Wall, A Closure evaluation of sizeresolved aerosol $\mathrm{pH}$ in the New England coastal atmosphere during summer. J Geophys Res D Atmos. 2004;109:1-16.

(11) Keene, WC, Stutz, J, Pszenny, AAP, Maben, JR, Fischer, E V., Smith, AM, von Glasow, R, Pechtl, S, Sive, BC, Varner, RK Inorganic chlorine and bromine in coastal New England air during summer. J Geophys Res Atmos. 2007;112:1-15.

(12) Kim, S, Huey, LG, Stickel, RE, Pierce, RB, Chen, G, Avery, MA, Dibb, JE, Diskin, GS, Sachse, GW, McNaughton, CS, et al. Airborne Measurements of $\mathrm{HCl}$ from the Marine Boundary Layer to the Lower Stratosphere over the North Pacific Ocean during INTEXB. Atmos. Chem. Phys. Discuss. 2008;8:3563-3595.

(13) Keene, WC, Long, MS, Pszenny, a. a. P, Sander, R, Maben, JR, Wall, a. J, O’Halloran, TL, Kerkweg, a., Fischer, E V., Schrems, O Latitudinal variation in the multiphase chemical processing of inorganic halogens and related species over the eastern North and South Atlantic Oceans. Atmos Chem Phys Discuss. 2009;9:11889-11950.

(14) Lawler, MJ, Sander, R, Carpenter, LJ, Lee, JD, Von Glasow, R, Sommariva, R, Saltzman, ES $\mathrm{HOCl}$ and $\mathrm{Cl}_{2}$ observations in marine air. Atmos Chem Phys. 2011;11:7617-7628.

(15) Crisp, TA, Lerner, BM, Williams, EJ, Quinn, PK, Bates, TS, Bertram, TH Observations of gas phase hydrochloric acid in the polluted marine boundary layer. J Geophys Res. 2014;119:6897-6915, doi:10.1002/2013JD020992. 
(16) Nassar, R, Bernath, PF, Boone, CD, Clerbaux, C, Coheur, PF, Dufour, G, Froidevaux, L, Mahieu, E, McConnell, JC, McLeod, SD, et al. A global inventory of stratospheric chlorine in 2004. J Geophys Res Atmos. 2006;111:1-13.

(17) US Environmental Protection Agency Hydrochloric Acid (Hydrogen Chloride) 7647-01-0. 1992, pp 1-4.

(18) Franey, JP, Graedel, TE Corrosive effects of mixtures of pollutants. J Air Pollut Control Assoc. 1985;35:644-648.

(19) Loupa, G, Charpantidou, E, Karageorgos, E, Rapsomanikis, S The chemistry of gaseous acids in medieval churches in Cyprus. Atmos Environ. 2007;41:9018-9029.

(20) Wingenter, OW, Kubo, MK, Blake, NJ, Smith, TW, Blake, DR, Rowland, FS Hydrocarbon and halocarbon measurements as photochemical and dynamical indicators of atmospheric hydroxyl, atomic chlorine, and vertical mixing obtained during Lagrangian flights. J Geophys Res. 1996;101:4331-4340.

(21) Bannan, TJ, Booth, AM, Bacak, A, Muller, JBA, Leather, KE, Le Breton, M, Jones, B, Young, D, Coe, H, Allan, J, et al. The first UK measurements of nitryl chloride using a chemical ionizationmass spectrometer in central London in the summer of 2012, and an investigation of the role of $\mathrm{Cl}$ atom oxidation. J Geophys Res Atmos. 2015;120:56385657.

(22) Osthoff, HD, Roberts, JM, Ravishankara, AR, Williams, EJ, Lerner, BM, Sommariva, R, Bates, TS, Coffman, D, Quinn, PK, Dibb, JE, et al. High levels of nitryl chloride in the polluted subtropical marine boundary layer. Nat Geosci. 2008;1:324-328.

(23) Platt, U, Hönninger, G The role of halogen species in the troposphere. Chemosphere. 2003;52:325-338.

(24) Young, CJ, Washenfelder, RA, Edwards, PM, Parrish, DD, Gilman, JB, Kuster, WC, Mielke, LH, Osthoff, HD, Tsai, C, Pikelnaya, O, et al. Chlorine as a primary radical: evaluation of methods to understand its role in initiation of oxidative cycles. Atmos Chem Phys. 2014;14:3427-3440.

(25) Pszenny, AAP, Keene, WC, Jacob, DJ, Fan, S, Maben, JR, Zetwo, MP, Springer-Young, $\mathrm{M}$, Galloway, JN Evidence of inorganic chlorine gases other than hydrogen chloride in marine surface air. Geophys Res Lett. 1993;20:699-702.

(26) Behnke, W, George, C, Scheer, V, Zetzsch, C Production and decay of CINO2 from the reaction of gaseous $\mathrm{N} 2 \mathrm{O} 5$ with $\mathrm{NaCl}$ solution: Bulk and aerosol experiments. J Geophys Res Atmos. 1997;102:3795-3804.

(27) Thornton, JA, Kercher, JP, Riedel, TP, Wagner, NL, Cozic, J, Holloway, JS, Dube, WP, Wolfe, GM, Quinn, PK, Middlebrook, AM, et al. A large atomic chlorine source inferred from mid-continental reactive nitrogen chemistry. Nature. 2010;464:271-274.

(28) Mielke, LH, Furgeson, A, Odame-ankrah, CA, Osthoff, HD Ubiquity of CINO2 in the urban boundary layer of Calgary, Alberta, Canada. Can J Chem. 2016;94:1-10.

(29) Wong, JPS, Carslaw, N, Zhao, R, Zhou, S, Abbatt, JPD Observations and impacts of bleach washing on indoor chlorine chemistry. Indoor Air. 2017;27:1082-1090.

(30) Howard, C, Corsi, RL Volatilization of chemicals from drinking water to indoor air: The role of residential washing machines. J Air Waste Manag Assoc. 1998;48:907-914.

(31) Olson, DA, Corsi, RL In-home formation and emissions of trihalomethanes: The role of residential dishwashers. J Expo Anal Environ Epidemiol. 2004;14:109-119.

(32) Kim, E, Little, JC, Chiu, N Estimating Exposure to Chemical Contaminants in Drinking Water. Environ Sci Technol. 2004;38:1799-1806. 
(33) Legay, C, Rodriguez, MJ, Sadiq, R, Sérodes, JB, Levallois, P, Proulx, F Spatial variations of human health risk associated with exposure to chlorination by-products occurring in drinking water. J Environ Manage. 2011;92:892-901.

(34) Guilherme, S, Rodriguez, MJ Occurrence of regulated and non-regulated disinfection byproducts in small drinking water systems. Chemosphere. 2014;117:425-432.

(35) Newfoundland and Labrador Department of Environment and Climate Change Newfoundland and Labrador Water Resources Portal.

(36) Health Canada Guidelines for Canadian Drinking Water Quality: Guideline Technical Document Chlorine; Ottawa, ON, 2009.

(37) Rothman, LS, Gordon, IE, Babikov, Y, Barbe, A, Chris Benner, D, Bernath, PF, Birk, M, Bizzocchi, L, Boudon, V, Brown, LR, et al. The HITRAN2012 molecular spectroscopic database. J Quant Spectrosc Radiat Transf. 2013;130:4-50.

(38) Crosson, ER A cavity ring-down analyzer for measuring atmospheric levels of methane, carbon dioxide, and water vapor. Appl Phys B Lasers Opt. 2008;92:403-408.

(39) Picarro Picarro G2108 HCl CRDS Analyzer; Santa Clara, CA, 2016.

(40) Isaacs, K, Burke, J, Smith, L, Williams, R Identifying housing and meteorological conditions influencing residential air exchange rates in the DEARS and RIOPA studies: development of distributions for human exposure modeling. J Expo Sci Environ Epidemiol. 2013;23:248-258.

(41) Chan, WR, Nazaroff, WW, Price, PN, Sohn, MD, Gadgil, AJ Analyzing a database of residential air leakage in the United States. Atmos Environ. 2005;39:3445-3455.

(42) Kowal, SF, Allen, SR, Kahan, TF Wavelength-resolved photon fluxes of indoor light sources: Implications for HOx production. Environ Sci Technol. 2017;51:10423-10430. Maric, D, Burrows, JP, Meller, R, Moortgat, GK A study of the UV-visible chlorine absorption spectrum of molecular. J Photochem Photobiol A Chem. 1993;70:205-214.

(44) Barnes, RJ, Sinha, A, Michelson, HA Assessing the contribution of the lowest triplet state to the near-UV absorption spectrum of HOCl. J Phys Chem A. 1998;102:8855-8859.

(45) Ghosh, B, Papanastasiou, DK, Talukdar, RK, Roberts, JM, Burkholder, JB Nitryl chloride (CINO2): UV/vis absorption spectrum between 210 and $296 \mathrm{~K}$ and $\mathrm{O}(3 \mathrm{P})$ quantum yield at 193 and $248 \mathrm{~nm}$. J Phys Chem A. 2012;116:5796-5805.

(46) Burkholder, JB, Sander, SP, Abbatt, J, Barker, JR, Huie, RE, Kolb, CE, Kurylo, MJ, Orkin, VL, Wilmouth, DM, Wine, PH Chemical Kinetics and Photochemical Data for Use in Atmospheric Studies Evaluation No.18. JPL Publication 15-10. Jet Propulsion Laboratory, Pasadena, California 2015, pp 1-153.

(47) Nelson, HH, Johnston, HS Kinetics of the reaction of $\mathrm{Cl}$ with $\mathrm{ClNO}$ and $\mathrm{CINO} 2$ and the photochemistry of CINO2. J Phys Chem. 1981;85:3891-3896.

(48) Burkholder, JB, Sander, SP, Abbatt, J, Barker, JR, Huie, RE, Kolb, CE, Kurylo, MJ, Orkin, VL, Wilmouth, DM, Wine, PH, et al. Chemical Kinetics and Photochemical Data for Use in Atmospheric Studies Evaluation Number 15. JPL Publ 15-10. 2006; California:1-153.

(49) Gomez Alvarez, E, Amedro, D, Afif, C, Gligorovski, S, Schoemaker, C, Fittschen, C, Doussin, J-F, Wortham, H Unexpectedly high indoor hydroxyl radical concentrations associated with nitrous acid. Proc Natl Acad Sci. 2013;

(50) Weschler, CJ, Shields, HC Production of the hydroxyl radical in indoor air. Environ Sci Technol. 1996;30:3250-3258.

(51) Weschler, CJ, Nazaroff, WW Growth of organic films on indoor surfaces. Indoor Air. 
2017;No.May1-12.

(52) Stockwell, CE, Yokelson, RJ, Kreidenweis, SM, Robinson, AL, Demott, PJ, Sullivan, RC, Reardon, J, Ryan, KC, Griffith, DWT, Stevens, L Trace gas emissions from combustion of peat, crop residue, domestic biofuels, grasses, and other fuels: Configuration and Fourier transform infrared (FTIR) component of the fourth Fire Lab at Missoula Experiment (FLAME-4). Atmos Chem Phys. 2014;14:9727-9754.

(53) Souci, S, Fachmann, W, Kraut, H Food Composition and Nutrition Tables, Die Zusammensetzung der Lebensmittel - Nährwert-Tabellen, La composition des aliments Tableaux des valeurs nutritives, 3rd ed.; Wissenschaftliche Verlagsgesellschaft: Stuttgart, Germany, 1989.

(54) Schnabl, H, Raschke, K Potassium chloride as stomatal osmoticum in Allium cepa L., a species devoid of starch in guard cells. Plant Physiol. 1980;65:88-93.

(55) Heckman, JR Chlorine. In CRC Handbook of Plant Nutrition; 2006; pp 279-288.

(56) Dasgupta, PK, Campbell, SW, Al-Horr, RS, Ullah, SMR, Li, J, Amalfitano, C, Poor, ND Conversion of sea salt aerosol to $\mathrm{NaNO} 3$ and the production of $\mathrm{HCl}$ : Analysis of temporal behavior of aerosol chloride/nitrate and gaseous $\mathrm{HCl} / \mathrm{HNO} 3$ concentrations with $\mathrm{AIM}$. Atmos Environ. 2007;41:4242-4257.

(57) Roberts, JM, Veres, P, Warneke, C, Neuman, JA, Washenfelder, RA, Brown, SS, Baasandorj, M, Burkholder, JB, Burling, IR, Johnson, TJ, et al. Measurement of HONO, $\mathrm{HNCO}$, and other inorganic acids by negative-ion proton-transfer chemical-ionization mass spectrometry (NI-PT-CIMS): application to biomass burning emissions. Atmos Meas Tech. 2010;3:981-990. 